Saudi Journal of Biomedical Research

Abbreviated Key Title: Saudi J Biomed Res ISSN 2518-3214 (Print) |ISSN 2518-3222 (Online)

\title{
The Effect of Leverage, Company Size, Growth Opportunity, and Financial Difficulties on Hedging Decisions in Manufacturing Companies Listed in Indonesia Stock Exchange for the Period 2016-2018
}

Maryani*, Yudhi Herliansyah

Universitas Mercu Buana, Jl. Raya, RT.4/RW.1, Meruya Sel., Kec. Kembangan, Jakarta, Daerah Khusus Ibukota Jakarta 11650, Indonesia

DOI: $10.36348 /$ sjbr.2020.v05i11.001

| Received: 16.10 .2020 | Accepted: 31.10.2020 | Published: 05.11.2020

*Corresponding author: Maryani

\section{Abstract}

The risk of international trade transactions occurs because of the risk of fluctuations in foreign currency exchange rates. Hedging derivatives is a part of risk management carried out by companies to overcome significant impacts on unexpected changes in the value of foreign currencies. The purpose of this study was to determine the effect of leverage, company size, growth opportunity and financial difficulties on hedging decisions. This research was conducted at manufacturing companies listed on the Indonesia Stock Exchange for the 2016-2018 period. This study has a total population of 420 and is calculated by purposive sampling in accordance with the criteria for a sample of 216 out of 140 companies observed. The results of this study indicate that there is no effect of leverage, growth opportunity and financial difficulties on hedging decisions, while firm size has an effect on hedging decisions.

Keywords: Leverage, firm size, growth opportunity, financial difficulties, hedging decisions.

Copyright (9) 2020 The Author(s): This is an open-access article distributed under the terms of the Creative Commons Attribution 4.0 International License (CC BY-NC 4.0) which permits unrestricted use, distribution, and reproduction in any medium for non-commercial use provided the original author and source are credited.

\section{Preliminary}

The rupiah exchange rate against the United States dollar (USD) in the 3rd week of December 2018 weakened further to the level of IDR 14,617 / USD due to a trade war whose the stability could not be ascertained (Sindonews.com).

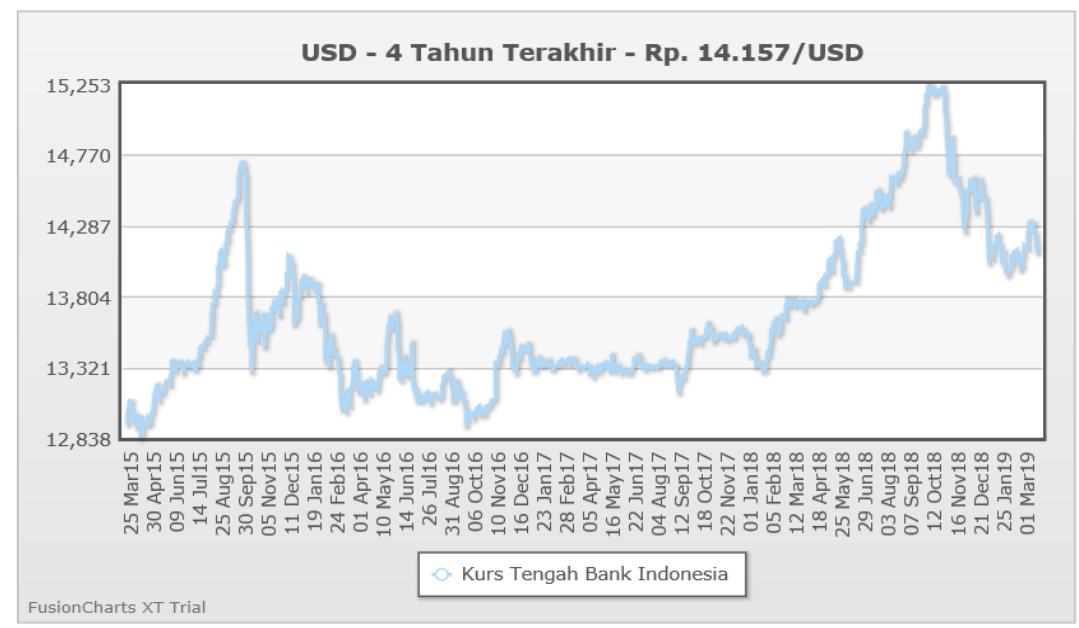

Because of the above phenomenon, it is suggested for large companies to hedge or hedge for the use of foreign currencies in the company's buying and selling activities. Besides domestic trade relations, the company also has international trade relations that involve foreign companies, where the problems in companies that carry out international trade will be more complicated than companies that only transact on the domestic market due to the use of different currencies in each different country [1]. 
International trade transactions that are not carried out in cash result in debt or receivables in foreign currency which may result in losses or gains to the company. The problem will be more complicated for companies that have made international transactions than for companies that rely solely on domestic transactions [2].

Cost incurred as a result of foreign exchange exposure contained in the financial statements are a form of company loss, where the impact of foreign currency exchange rate losses on the company can be seen from the decline in profit from financial statements, a decrease in earnings per share and a decrease in share prices, which have an impact on the decline in the number of investors which resulted in the loss of company funding sources. Good and proper company management can overcome the risks that potentially will occur which can be interpreted as risk management [3].

Referring to the phenomenon and the elaboration of several opinions expressed, hedging can be influenced by several variables that refer to the results of research, which are leverage and Growth Opportunities [2], Liquidity [1] and Financial Difficulties [4].

Based on the description on the background and the presence of research gaps in previous studies, the title of this research is "Leverage, Company Size, Growth Opportunity and Financial Difficulties on Hedging Decisions in Manufacturing Companies Listed on the Indonesia Stock Exchange 2016-2018 period.

\section{LITERATURE} Agency Theory

Agency theory arises from a work relationship between an agent and one or more people (principal) to provide services and delegate authority to agents for decision making $[5,6]$. Thus, it is obligatory for an agent to carry out the mandate that it carries with the full responsibility given by the principal to an agent. The same concept of agency theory is also presented by Anthony and Govindarajan in Siagian [7].

The companies whose the capital ownership consists of shares, the shareholders act as the principal, and the CEO (Chief Executive Officer) as the agent, where the CEO is employed by the shareholders to act in accordance with the interests of the principal.

The large portion of internal information owned by the company manager is compared to the owner or the principal, so a company manager is obliged to provide a signal about the state of the company which can be in the form of disclosing accounting information such as financial statements. Given the importance of financial reports for users of external information, especially because these communities are the most uncertain in receiving this information [8]. Manager's commitment to the organization and the simultaneous implementation of an internal control system has a positive effect on the quality of financial reports [9].

\section{SIGNALING THEORY}

Signal theory explains the reasons for companies to provide financial statement information to external parties in relation to the presence of asymmetrical information between company management and outside parties. The company management has more information in the form of financial reports, company policies or other information that the company management does voluntarily. The company management also knows the company's prospects in the future.

Signal theory describes how a company should provide signals in the form of information about what management has done to realize the principal's wishes, signals in the form of promotions or other information that shows that the company is better than other companies [10].

Market reactions are determined by the interpretation of the information received by market participants, which can be in the form of good signals (good news) or bad signals (bad news). If the signal is good for investors, it will result in changes in stock prices where an increase in stock prices will result in an increase in stock returns.

\section{Risk Management}

Losses caused by an undesirable event are interpreted as risks. Where risk is identified based on factors that cause, among others: risk caused by movements in market prices (for example: stock prices, exchange rates and interest rates) which are categorized as market risk. The risk caused by default (default) is categorized as credit risk. Meanwhile, the operational risk category is the risk caused by mistakes or failures of people or systems, processes or external factors [11]. Risk management is also defined by Djojosoedarso [3] as the implementation of management functions in managing risks faced by organizations or companies, families, and communities. Changes in exchange rates against foreign currencies is a form of financial risk where risk management can reduce this financial risk.

\section{Definition of Hedging}

Hedging is a policy or activity carried out by a company as a result of a decision to mitigate or reduce risk or protect the value position of the company's assets or underlying liabilities against the risk of fluctuations in interest rates and currency values in the future. And hedging is a contract whose existence aims to protect the company from market risk [12]. 
Hedging is a policy or activity carried out by a company as a result of a decision to mitigate or reduce risk or protect the value position of the company's assets or underlying liabilities against the risk of fluctuations in interest rates and currency values in the future. And hedging is a contract whose existence aims to protect the company from market risk [12].

\section{Leverage}

Leverage is a ratio that describes the relationship between corporate debt to capital, which can be used to see the extent to which the company's operations are financed by external debt with the company's ability in the form of corporate capital [13]. A different thing is revealed by Fahmi [14] that leverage is defined as a measure used to analyze financial statements that show the amount of collateral that will be available to creditors.

The ratio can be measured using debt and capital measuring instruments, where with this ratio the company's ability can be seen to what extent the company is financed by debt or external parties. This ratio is calculated using the proxy Debt Equity Ratio (DER) with the formula below:

$$
\text { DER }=\frac{\text { Total Debt }}{\text { Total Equity }} \times 100 \%
$$

\section{Company Size}

According to Budiman and Harnovinsah [15], company size is described by the size of a company which can be shown by total assets or total net sales. The bigger of the company size, so the bigger of the company's total assets and sales. And the bigger of the assets, then the greater of the capital invested, and the more sales, the more circulation of money in the company. So it can be concluded that company size is a measure of the size of the assets owned by the company.

\section{Growth Opportunity}

Benito in Goenawan [16] explains that growth opportunity is an effort to manage money by reinvesting the money in certain fields with the aim of getting benefits in the future. Prihantoro [17] states that the need for funds to finance expansion will be higher in line with the higher growth rate of a company. Systematically Growth can be formulated:

$$
\text { Growth Opportunity }=\frac{\text { Total Aset }_{t}-\text { Total Aset }_{t-1}}{\text { Total Aset }_{t-1}}
$$

\section{Financial Distress}

Financial distress occurs when a company's financial obligations (debt) and dividends cannot be fulfilled [18]. Setyorini and Ardiati [19] suggest that bankruptcy prediction is a means of detecting and predicting the possibility of financial difficulties starting from liquidity difficulties to the potential for bankruptcy. According to Edward I Altman [20] in his book Corporate Financial Distress, (Supardi, 2003: 73) explains that "Z-Score is a score determined from the standard calculation times financial ratios that indicate the level of the possibility of company bankruptcy". Altman conducted a corporate bankruptcy study in 1966 of 66 companies and half of the sample companies were already bankrupt companies. The research resulted in 5 ratios, namely liquidity ratios, profitability, economic profitability, market value ratios and activity ratios which can be combined between bankrupt companies, gray areas and healthy ones. The formulation from Altman Zscore is as follows:

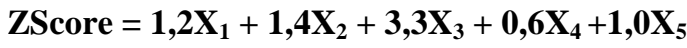

Information:

$$
\begin{aligned}
& \mathrm{X}_{1}=\text { Working Capital/Total Assets } \\
& \mathrm{X}_{2}=\text { Retained Earnings/Total Assets } \\
& \mathrm{X}_{3}=\text { EBIT/Total Assets } \\
& \mathrm{X}_{4}=\text { Market Value Equity/Total Assets } \\
& \mathrm{X}_{5}=\text { Sales/Total Assets }
\end{aligned}
$$

Altmant Z-Score ratio analysis can be applied to both public and closed companies, and to manufacturing companies or service companies.

In the research that the authors conducted on the variable financial distress (financial distress) using the Altman Zscore proxy which is calculated for the period from 2016-2018 in manufacturing companies, so that the company can consider or make hedging decisions.

\section{HYPOTHESIS}

1. H1: Leverage has a positive effect on hedging decisions in manufacturing companies listed on the Indonesia Stock Exchange for the period 2016-2018;

2. H2: Company size has a positive effect on hedging decisions in manufacturing companies listed on the Indonesia Stock Exchange for the period 2016-2018;

3. H3: Growth Opportunity has a positive effect on hedging decisions for manufacturing companies listed on the Indonesia Stock Exchange for the period 2016-2018;

4. H4: Financial difficulties have a positive influence on hedging decisions in manufacturing companies listed on the Indonesia Stock Exchange for the period 20162018.

\section{RESEARCH DESIGN AND METHOD}

This study aims to test the hypothesis. The type of data in this research is panel data, namely secondary data which has the characteristics of cross section and time series simultaneously. The population of this study was 420 out of 140 companies that were observed and obtained a sample of 216 respondents 
using purposive sampling. The test instrument used was binary logistic regression analysis with SPSS 25.0.

\section{RESULTS AND STUDY \\ Description Analysis}

Descriptive analysis aims to analyze the characteristics of a data in the form of data distribution which includes the maximum value ( $\max )$, minimum value (min), average (mean) and standard deviation.

Table-1: Descriptive Statistics Test Results

Descriptive Statistics

\begin{tabular}{|c|c|c|c|c|c|c|c|c|c|}
\hline & $\mathrm{N}$ & Range & $\begin{array}{c}\text { Minimu } \\
\mathrm{m}\end{array}$ & $\begin{array}{c}\text { Maximu } \\
\mathrm{m}\end{array}$ & Sum & \multicolumn{2}{|c|}{ Mean } & $\begin{array}{c}\text { Std. } \\
\text { Deviation }\end{array}$ & $\begin{array}{c}\text { Varianc } \\
\mathrm{e}\end{array}$ \\
\hline & Statistic & Statistic & Statistic & Statistic & Statistic & Statistic & $\begin{array}{l}\text { Std. } \\
\text { Error }\end{array}$ & Statistic & Statistic \\
\hline Lev & 216 & 7.97 & 1.23 & 9.20 & 386.09 & 1.7874 & .11642 & 1.71105 & 2.928 \\
\hline FZ & 216 & 7.82 & 5.90 & 13.72 & 2344.92 & 10.8561 & .13831 & 2.03268 & 4.132 \\
\hline GO & 216 & 3.84 & -.37 & 3.47 & 34.59 & .1601 & .02235 & .32844 & .108 \\
\hline FD & 216 & 2.15 & 1.08 & 3.23 & 390.16 & 1.8063 & .03184 & .46800 & .219 \\
\hline $\begin{array}{l}\text { Valid N } \\
\text { (listwise) }\end{array}$ & 216 & & & & & & & & \\
\hline
\end{tabular}

1. Leverage variable using DER proxy (ratio of total debt to equity). The smallest DER value is 1.23 and the largest is 9.20 and the average value is 1.7874 , which means that the proportion of the ratio between total debt and total equity is 1.7874 times in the sample companies. A small DER value indicates that the company will more easily pay its debt obligations compared to companies that have a larger DER value. In other words, this indicates that the company in carrying out its operations and expanding does not use debt as the main source of corporate funding. And conditions like these for manufacturing companies are good.

2. Firm size using a logtotal asset proxy, where the size of the company is indicated by the size of the asset value. The higher the asset value, the bigger the company size, and vice versa. The sample company size with the smallest log asset value is 5.9 indicated by the company with assets valued at Idr. 789,137,743,984 and the largest log asset of 13.72 indicated by the company with assets valued at Idr. 38,292,205,983,731, while the average log asset value is 10,8561 . This shows that the sample companies according to the company size criteria Law no. 20 of 2008 is categorized as a large company.

3. The Growth Opportunity variable uses a proxy for the total asset value of the current year minus the total assets of the previous year divided by the total assets of the previous year. So that shows that if the total assets of the current year are greater, it will show good company growth. From the research results, the minimum value of the growth rate has a value of -0.37 which occurs in sample companies that experience a decrease in asset value due to capital difficulties during the observation period so that the company sells one of its assets. The maximum value is 3.47 and the average value is 0.1601 and the standard deviation is 0.32844 . This shows that on average the sample companies during the observation period experienced growth but not too high.

4. The variable of financial distress based on the table above is proxied by the Altman Z-score having the smallest value of 1.08 and the largest value of 3.23, and the average value of 1.8063 with a standard deviation of 0.46800 . These results indicate that not all sample companies in this study were in good financial condition during the observation period. The cut off of the Z-score for the category of good company conditions is $>2.6$. The greater the Z-score, the better the company's financial condition.

\section{Overall Test using the G Test}

Below is STAGE 0, which is the stage when the independent variable has not been included in the research model.

Table-2: Block 0: Beginning Block

\begin{tabular}{|c|c|c|c|}
\hline \multicolumn{4}{|c|}{ Iteration History $^{\mathbf{a}, \mathrm{b}, \mathrm{c}}$} \\
\hline \multirow{2}{*}{\multicolumn{2}{|c|}{ Iteration }} & \multirow[t]{2}{*}{-2 Log likelihood } & Coefficients \\
\hline & & & Constant \\
\hline \multirow[t]{3}{*}{ Step 0} & 1 & 273.607 & .685 \\
\hline & 2 & 273.567 & .714 \\
\hline & 3 & 273.567 & .714 \\
\hline \multicolumn{4}{|c|}{ a. Constant is included in the model. } \\
\hline \multicolumn{4}{|c|}{ b. Initial -2 Log Likelihood: 273.567} \\
\hline \multicolumn{4}{|c|}{ c. Estimation terminated at iteration number 3 because parameter estimates changed by less than .001 . } \\
\hline
\end{tabular}


Table-3: Block 1: Method = Enter

\begin{tabular}{|c|c|c|c|c|c|c|}
\hline \multicolumn{7}{|c|}{ Iteration History $^{\mathrm{a}, \mathrm{b}, \mathrm{c}, \mathrm{d}}$} \\
\hline \multirow[b]{2}{*}{ Iteration } & \multirow{2}{*}{$\begin{array}{c}-2 \log \\
\text { likelihood }\end{array}$} & \multicolumn{5}{|c|}{ Coefficients } \\
\hline & & Constant & Lev & $\mathrm{FZ}$ & GO & FD \\
\hline \multirow[t]{4}{*}{ Step 1} & 250.321 & -3.236 & .092 & .299 & .013 & .281 \\
\hline & 249.555 & -3.791 & .124 & .340 & .015 & .360 \\
\hline & 249.553 & -3.827 & .127 & .342 & .014 & .366 \\
\hline & 249.553 & -3.827 & .127 & .343 & .014 & .366 \\
\hline \multicolumn{7}{|c|}{$\begin{array}{l}\text { a. Method: Enter } \\
\text { b. Constant is included in the model. } \\
\text { c. Initial -2 Log Likelihood: } 273.567\end{array}$} \\
\hline
\end{tabular}

Based on the research results in Table-2 (Bock 0: beginning) gets a value of -2Log Likelihood: 273,567 while in Table-3 (Block 1: method = enter) by entering the independent variable into the model, the $-2 \mathrm{Log}$ Likelihood value becomes 250,321 or decreases by 23,246 so that this This identifies that the regression model used for company-wide research is a good regression model or a model that is hypothesized to be fit with the data, and the addition of independent variables to the model has improved the fit model.

\section{Partial Test}

The partial test serves to determine the significance of the individual constant parameters, which are shown in the table below with the following hypothesis:

$$
\begin{aligned}
& H_{0}: \beta_{\mathrm{n}}=0 \\
& H_{1}: \beta_{\mathrm{n}}=0 ; \mathrm{n}=1,2, \ldots \ldots, p
\end{aligned}
$$

Table-4: Estimasi Parameter

\begin{tabular}{|c|c|c|c|c|c|c|c|c|c|}
\hline & \multirow[b]{2}{*}{ B } & \multirow[b]{2}{*}{ S.E. } & \multirow[b]{2}{*}{ Wald } & \multirow[b]{2}{*}{ df } & \multirow[b]{2}{*}{ Sig. } & \multirow[b]{2}{*}{$\operatorname{Exp}(B)$} & \multicolumn{2}{|c|}{$95 \%$ C.I.for EXP(B) } \\
\hline & & & & & & & & Lower & Upper \\
\hline \multirow[t]{5}{*}{ Step $1^{\mathrm{a}}$} & Lev & .127 & .106 & 1.433 & 1 & .231 & 1.135 & .922 & 1.397 \\
\hline & FS & .343 & .078 & 19.444 & 1 & .000 & 1.408 & 1.210 & 1.640 \\
\hline & GO & .014 & .496 & .001 & 1 & .977 & 1.014 & .384 & 2.682 \\
\hline & FD & .366 & .365 & 1.004 & 1 & .316 & 1.442 & .705 & 2.951 \\
\hline & Constant & -3.827 & 1.078 & 12.596 & 1 & .000 & .022 & & \\
\hline
\end{tabular}

Variables in the Equation

a. Variable(s) entered on step 1: Lev, FS, GO, FD.

Source: Results of Data Processing, 2019

In Table-4 Variables in the equation above:

1. If the independent variable $P$ value wald test (Sig) $<0.05$, it means that the variable has a significant partial effect on Y in the model.

2. If the independent variable $P$ value wald test (Sig) $>0.05$, it means that the variable does not have a significant partial effect on $\mathrm{Y}$ in the model.

Then the results of the partial test or Wald test are: that the firm size variable (Fim Size) has a Sig or Wald test $\mathrm{p}$ value of $0.000<0.05$ so that $\mathrm{H} 1$ is accepted which means that Company Size has a significant partial effect on $\mathrm{Y}$ or Hedging. While other variables, namely LEV, GO and FD accept $\mathrm{HO}$ or not significant, because the three $\mathrm{p}$-value of the Wald test>0.05.

\section{Model Fit Test}

Tests conducted to determine whether there is a difference between the results of the observations and the results of the prediction of the model with the following hypotheses:

H0: The model is appropriate (there is no significant difference between the results of the observations and the results of the model predictions)

H1: The model is not suitable (there is a significant difference between the results of the observations and the results of the prediction of the model)

The criteria proposed is reject $\mathrm{H} 0$ if the value of Sig $<0.05$. 
Table-5: Hosmer dan Lemeshow Test Hosmer and Lemeshow Test

\begin{tabular}{|l|r|r|r|}
\hline Step & Chi-square & df & Sig. \\
\hline 1 & 2.440 & & 8 \\
\hline
\end{tabular}

Source: Results of Data Processing, 2019

The Hosmer and Lemeshow test can also be used to test the feasibility of a simultaneous model.
Based on Table-5 above, the Chi-Square value is 2,440 with a significance value of .964 , which means more than 0.05 , then receiving $\mathrm{H} 0$, which can be concluded that the resulting model in binary logistic regression, namely hedging is influenced by various independent variable factors. It also shows that there is no significant difference between the results of the observations and the prediction of the model. With a 95\% confidence level that the logistic regression model used is sufficient to explain the data or it can be said that this research model has a good goodness-of-fit so that it can be used as an accurate model.

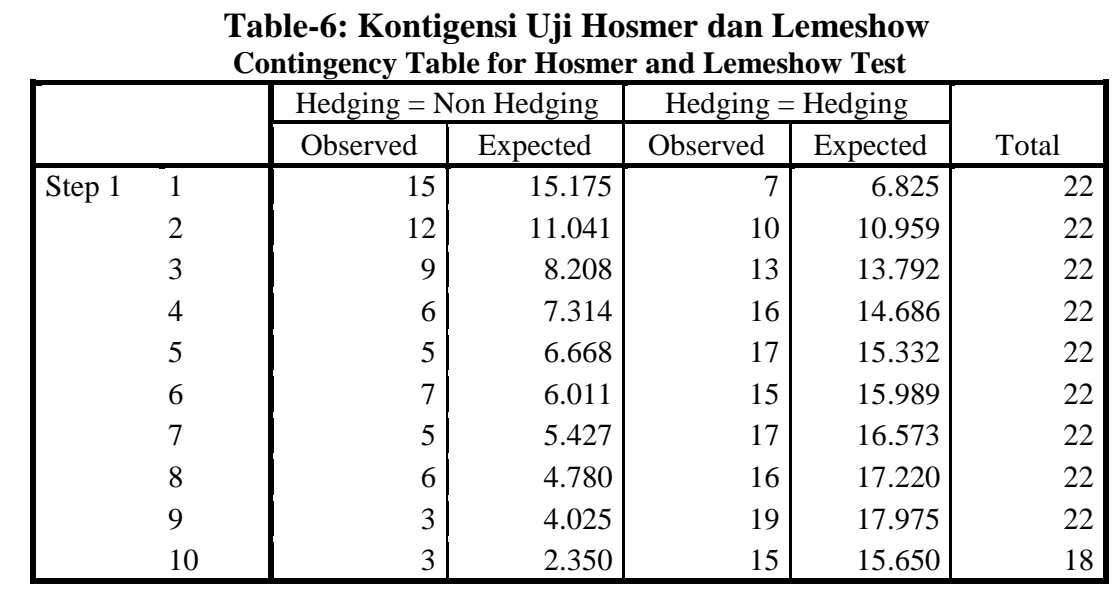

Source: Results of Data Processing, 2019

Based on Table- 6 on observation 0 (NonHedging) for the hedging case based on observations of 15 while the expected is 15,175 . And in observation 1 (hedging) for the case of hedging based on observations of a number of 7 and the expected is 6,825 . This shows that there is no significant difference between observations and expectations, so it can be concluded that the model used is appropriate.

\section{Interpretasi Koefisien Parameter}

a. Interpretasi Odds Ratio

Based on Table-3, the Odds Ratio value is shown in the table "variables in the equation" in column $\operatorname{Exp}(\mathrm{B})$ :

1. Exp (B) observation 1 shows that companies with high leverage tend to hedge 1,135 times compared to those with low leverage.
2. Exp (B) observation 2 shows that companies with high Firm Size tend to hedge 1,408 times compared with low Firm Size.

3. Exp (B) observation 3 shows that companies with high Growth Opportunities tend to hedge 1.014 times compared to those with low Growth Opportunities.

4. Exp (B) observation 4 shows that companies with high financial distress tend to hedge 1,442 times compared to those with low financial distress.

Based on Table-3, the independent variables that have the greatest opportunity to hedge is the financial distress variable because it produces the highest Exp (B) value, which is 1,442 compared to the $\operatorname{Exp}(\mathrm{B})$ value for the other variables.

b. Model Logistic Biner

After carrying out the overall test (simultaneously), the binary logistic model is obtained as follows:

$$
\begin{gathered}
\operatorname{Ln}\left(\frac{p}{1-p}\right)=B_{0}+B_{1} L E V+B_{2} F S+B_{3} G O+B_{4} F D \\
\operatorname{Ln}\left(\frac{p}{1-p}\right)=-3,827+0,127 L E V+0,343 F S+0,014 G O+0,366 F D
\end{gathered}
$$


Which is $\operatorname{Ln}\left(\frac{p}{1-p}\right)=$ LOGIT.

Or if it use the derivative formula, it is as follows:

$$
p=\frac{e^{(-3,827+0,127 L E V+0,343 F S+0,014 G O+0,366 F D)}}{\left(1+e^{(-3,827+0,127 L E V+0,343 F S+0,014 G O+0,366 F D)}\right)}
$$

Based on the logistic regression model above, it can be concluded that the company opportunity to do hedging is influenced by the Leverage factor of 0.127 , Firm Size of 0.343, Growth Opportunities of 0.014 and Financial Distress of 0.366.

c. Summary Model

Berdasarkan hasil pengujian maka di dapat hasil pada tabel dibawah ini:

Table-7: Summary Model Model Summary

\begin{tabular}{|l|r|r|r|}
\hline Step & $\begin{array}{c}-2 \text { Log } \\
\text { likelihood }\end{array}$ & $\begin{array}{c}\text { Cox \& Snell R } \\
\text { Square }\end{array}$ & $\begin{array}{c}\text { Nagelkerke R } \\
\text { Square }\end{array}$ \\
\hline 1 & $249.553^{\mathrm{a}}$ & .105 & .147 \\
\hline
\end{tabular}

a. Estimation terminated at iteration number 4 because parameter estimates changed by less than .001 .

Source: Results of Data Processing, 2019

Based on Table-7 the model summary above shows the $-2 \log$ Likelihood value of 249,553 where the value is very large. In addition, from the Nagelkerke RSquare value of 0.147 or $14.7 \%$, the variability of the hedging model can be explained by the independent variable of $14.7 \%$, while the remaining $85.3 \%$ will be explained by other variables outside the model.

\section{Classification Accuracy}

Table-8: Classification Classification Table $^{\mathrm{a}}$

\begin{tabular}{|c|c|c|c|c|c|}
\hline & \multirow[b]{3}{*}{ Observec } & & \multicolumn{3}{|c|}{ Predicted } \\
\hline & & & \multicolumn{2}{|c|}{ Hedging } & \multirow{2}{*}{$\begin{array}{c}\text { Percentage } \\
\text { Correct }\end{array}$} \\
\hline & & & Non Hedging & Hedging & \\
\hline \multirow[t]{3}{*}{ Step 1} & Hedging & Non Hedging & 19 & 52 & 26.8 \\
\hline & & Hedging & 11 & 134 & 92.4 \\
\hline & Overall $\mathrm{F}$ & centage & & & 70.8 \\
\hline
\end{tabular}

\section{Source: Results of Data Processing, 2019}

Based on Table- 8 , the accuracy of the classification model shows that there are 19 nonhedging respondents while those who did hedging were 11. Non-hedging respondents were predicted to hedge as many as 52, and respondents who hedged and would still hedge were 134 companies. So overall the classification accuracy of the binary logistic regression model for the hedging and non-hedging categories is $70.8 \%$.
Study

Analysis of the Effect of Leverage on Hedging Decisions in Manufacturing Companies Listed on the Indonesia Stock Exchange for the Period 2016 2018

Based on the results of partial hypothesis testing (Table-3) which shows a significance value of 0.231 or which can be categorized that this significance value is greater than the alpha value, namely 0.05 $(0.231<0.05)$. This shows that from the partial test results there is no significant effect of the leverage variable on hedging decisions in Manufacturing Companies listed on the Indonesia Stock Exchange for the 2016-2018 Period (H1 is rejected).

The results of this study are in line with the results of research by Jiwandhana [21] which both result that leverage has no effect on hedging decisions. This shows that the high leverage indicated by the high debt to the company does not necessarily encourage the company to hedge. This is because the company feels that it is able to pay its debts and obligations, both short and long term, so that hedging is deemed unnecessary by the company to secure the company's financial position.

This result is contrary to the results of research from Munthe et al., [22] which proved that leverage has an effect on hedging.

Analysis of the Influence of Company Size on Hedging Decisions in Manufacturing Companies Listed on the Indonesia Stock Exchange Period 2016-2018

Based on the results of partial hypothesis testing (Table-3), where the logistic regression testing carried out in this study resulted in a Wald value of 19,444 and a significance value of 0,000 or less than an alpha value of 0.05 , this study proves that there is an effect that significant variable Firm Size (Firm Size) on hedging decisions ( $\mathrm{H} 2$ is accepted).

Company size has a positive effect on hedging, meaning that hedging is one of the ways to mitigate corporate risk due to exchange rate risk that cannot be avoided in large companies that tend to trade internationally using several foreign currencies [23]. The bigger the company, the greater the risk faced by the company so that it is necessary to apply stricter risk management compared to small companies.

The results of this study are in line with the results of research from Andardini [24] which both result that company size has a positive effect on hedging decisions. However, the results of this study contradict the results of research from Wulandari, Ruwanti and Manik [25] which resulted that company size had no effect on hedging decisions. 
Analysis of the Influence of Growth Opportunities on Hedging Decisions in Manufacturing Companies Listed on the Indonesia Stock Exchange for the Period 2016-2018

Based on the results of partial hypothesis testing (Table-3), the significance value is 0.977 or it can be categorized that this significance value is greater than the alpha value, namely 0.05 (0.977> 0.05). So based on the partial test results, it shows that there is no significant effect of the Growth Opportunity variable on hedging decisions in manufacturing companies listed on the Indonesia Stock Exchange for the 2016-2018 period (H3 rejected).

This indicates that the company prefers to conduct transactions with natural hedging, such as using the same currency in conducting business transactions with outside companies even though the company has good growth.

The results of this study are in line with the results of research by Wiryawan [26] which both result that growth opportunity has no effect on hedging decisions. However, the results of this study contradict the results of research by Bodroastuti, Paranita and Ratnasari [27] which resulted that Growth Opportunities had an effect on hedging decisions. The greater the company's growth, the higher the risk of financial difficulties because of the higher debt from external parties for business transactions with foreign companies in foreign currencies.

\section{Analysis of the Effect of Financial Difficulties on Hedging Decisions in Manufacturing Companies Listed on the Indonesia Stock Exchange for the Period 2016-2018}

Based on the results of partial hypothesis testing (Table-3), the significance value is 0.316 or it can be categorized that this significance value is greater than the alpha value, namely 0.05 (0.316> 0.05). So based on the partial test results, there is no significant effect of the Financial Distress variable on hedging decisions in Manufacturing Companies listed on the Indonesia Stock Exchange for the 2016-2018 Period (H4 rejected).

This indicates that companies with a high enough level of financial difficulty tend not to choose to hedge because the allocation of funds for hedging will be more burdensome for the company's finances. The results of this study are in line with the results of research by Wulandari, Ruwanti and Manik [25] which resulted that financial difficulties do not affect hedging decisions.

However, this study contradicts the results of Amrit Judge's [28] study which resulted in financial difficulties having a significant positive relationship with hedging decisions. The high Z-score value in most companies tends to hedge to protect the company's assets or a decrease in the Z-score value as a result of fluctuating foreign exchange rates.

\section{CONCLUSION}

Based on the results of the research and study presented in the previous chapter, the authors get the following conclusions:

1. There is no influence of Leverage on Hedging Decisions in Manufacturing Companies listed on the Indonesia Stock Exchange for the period 2016-2018;

2. There is an influence of company size on hedging decisions in manufacturing companies listed on the Indonesia Stock Exchange for the period 2016-2018;

3. There is no influence of Growth Opportunities on Hedging Decisions in Manufacturing Companies listed on the Indonesia Stock Exchange for the period 2016-2018;

4. There is no influence of financial difficulties on hedging decisions in manufacturing companies listed on the Indonesia Stock Exchange for the period 2016-2018.

\section{SUGGESTION}

Due to the limitations in this study, including the use of variables for the assessment of hedging decisions that still do not describe the probability of hedging decision making and the lack of sampling data observation period, the authors can provide suggestions for further researchers as follows:

1. Use of other hedging decision measurements such as types of derivatives in each company so that they are more comparable;

2. Using a wider sample population, such as using all companies listed on the Indonesia Stock Exchange, or using company external factors that are thought to be influencing factors in corporate hedging decision making, such as political and government policies, the Asean economic community and market developments money and capital markets.

\section{REFERENCES}

1. Dewi, K. R. U., \& Purnawati, K. (2016). Pengaruh market to book value dan likuiditas terhadap keputusan hedging pada perusahaan manufaktur di BEI. E-Jurnal Manajemen Universitas Udayana, 5(1).

2. Widyagoca, I. A., \& Lestari, P. V. (2016). Pengaruh Leverage, Growth Opportunities, Dan Liquidity Terhadap Pengambilan Keputusan Hedging Pt. Indosat Tbk. E-Jurnal Manajemen Universitas Udayana, 5(2):1282-1308.

3. Djojosoedarso, S. (2003). Prinsip-prinsip Manajemen Resiko dan Asuransi. Edisi Revisi. Jakarta: Salemba Empat.

4. Krisdian, N. P. C., \& Badjra, I. B. (2017). Pengaruh Ukuran Perusahaan, Tingkat Hutang, Dan Kesulitan Keuangan Terhadap Keputusan 
Hedging Pada Perusahaan Manufaktur Indonesia. E-Jurnal Manajemen Universitas Udayana, 6(3).

5. Jensen, M. C., \& Meckling, W. H. (1976). Theory of the firm: Managerial behavior, agency costs and ownership structure. Journal of financial economics, 3(4), 305-360.

6. Ujiyantho, M. A., \& Pramuka, B. A. (2007). Mekanisme corporate governance, manajemen laba dan kinerja keuangan. Simposium Nasional Akuntansi X, 10(6), 1-26.

7. Siagian, F. T., \& Tresnaningsih, E. (2011). The impact of independent directors and independent audit committees on earnings quality reported by Indonesian firms. Asian review of Accounting.

8. Lestari, L. S., \& Pamudji, S. (2013). Pengaruh Earnings Management terhadap Nilai Perusahaan Dimoderasi dengan Praktik Corporate Governance (Studi Empiris Pada Perusahaan Non Keuangan yang Terdaftar di Bursa Efek Indonesia Tahun 2008-2011) (Doctoral dissertation, Fakultas Ekonomika dan Bisnis).

9. Setiyawati, H. S. (2013). The effect of Internal Accountants' Competence, Managers' Commitment to Organizations and the Implementation of the Internal Control System on the Quality of Financial Reporting. International Journal of Business and Management Invention, 2(11), 19-27.

10. Hartono, S. (2012). Pengaruh Informasi Laba Dan Arus Kas Terhadap Harga Saham. Akurat: Jurnal Ilmiah Akuntansi, 3(7).

11. Sunaryo, A. (2009). Ornamen Nusantara: kajian khusus tentang ornamen Indonesia. Dahara Prize.

12. Subramanyam, K. R., \& Wild, J. J. (2013). Analisis Laporan Keuangan, Buku 2, Salemba Empat, Jakarta.

13. Harahap, F. R. (2013). Dampak urbanisasi bagi perkembangan kota di Indonesia. Society, 1(1), 3545.

14. Fahmi, I., \& Cremaschi, S. (2012). Process synthesis of biodiesel production plant using artificial neural networks as the surrogate models. Computers \& Chemical Engineering, 46, 105-123.

15. Budiman, S. (2016). Analisis Pengaruh Arus Kas, Leverage, Tingkat Pertumbuhan, Ukuran Perusahaan, Dan Profitabilitas Terhadap Kebijakan Dividen (Studi Pada Industri Manufaktur Yang Tercatat Pada Bursa Efek Indonesia Periode 2011-2013). 7(1):49-61.

16. Goenawan, S. I. (2013). Solusi Cerdas Revolusi Sistem Bunga/Nisbah Perbankan. Jakarta: PT. Puspa Swara.
17. Prihantoro, P. (2012). Estimasi Pengaruh Dividen Payout Ratio Pada Perusahaan Publik Di Indonesia.

18. Septivani, R., Dan, A. S. (2014). Pengaruh Kinerja Keuangan Perusahaan, Corporate Governance Dan Intellectual Capital Terhadap Kemungkinan Terjadinya Financial Distress (Studi Empiris Pada Perusahaan Non Jasa Keuangan Di Bursa Efek Indonesia). Jurnal Tekun, 2014:5(1):161-176. Fakultas Ekonomi Universitas Bakrie Dan Fakultas Ekonomi Universitas Tarumanagara.

19. Setyorini, T. N., \& Ardiati, A. Y. (2017). Pengaruh Potensi Kebangkrutan Perusahaan Publik Terhadap Pergantian Auditor.

20. Altman, E. I. (1983). Why businesses fail. The journal of business strategy, 3(4), 15.

21. Purba, F. N. Pengaruh Market To Book Value, Leverage, Profitabilitas, Dan Likuiditas Terhadap Keputusan Hedging Pada Perusahaan Manufaktur Yang Terdaftar Di Bursa Efek Indonesia Tahun 2012-2015.

22. Munthe, A. E. (2016). Analisis Faktor Yang Memperngaruhi Penggunaan Instrumen Derivatif Sebagai Penggambil Keputusan Hedging Pada Perusahaan Yang Terdaftar di Bursa Efek Indonesia. Universitas Sumatera Utara, Medan.

23. Sianturi, C. N., \& Pangestuti, I. R. D. (2015). Pengaruh Liquidity, Firm Size, Growth Opportunity, Financial Distress, Leverage dan Managerial Ownership terhadap Aktivitas Hedging dengan Instrumen Derivarif. Diponegoro Journal of Accounting, 4(4):1-13.

24. Andardini, W. R. (2016). Keputusan Hedging dan Faktor-faktor yang Mempengaruhi (Studi Empiris pada Perusahaan Manufaktur yang Terdaftar di BEI 2012-2014) (Doctoral dissertation, STIE PERBANAS SURABAYA).

25. Maulida, N., Manik, T., \& Ruwanti, S. (2020). Pengaruh Kepemilikan Manajerial, Kepemilikan Institusional, Kesempatan Investasi Terhadap Kebijakan Dividen Dengan Likuiditas Sebagai Variabel Pemoderasi Pada Perusahaan Manufaktur 2012-2016. Student Online Journal (SOJ) UMRAH-Ekonomi, 1(1), 196-209.

26. Wiryawan, K. G. (2016). Egg production and quality of quails fed diets with varying levels of methionine and choline chloride. Media Peternakan, 39(1), 34-39.

27. Bodroastuti, T., Paranita, E. S., \& Ratnasari, L. (2019). Faktor-faktor yang Berpengaruh terhadap Kebijakan Hedging Perusahaan di Indonesia. Valid Jurnal Ilmiah, 16(1), 71-84.

28. Clark, E. A., \& Judge, A. P. (2005). The motives for corporate hedging: the UK evidence. Research in Financial Economics, 1(1), 57-78. 